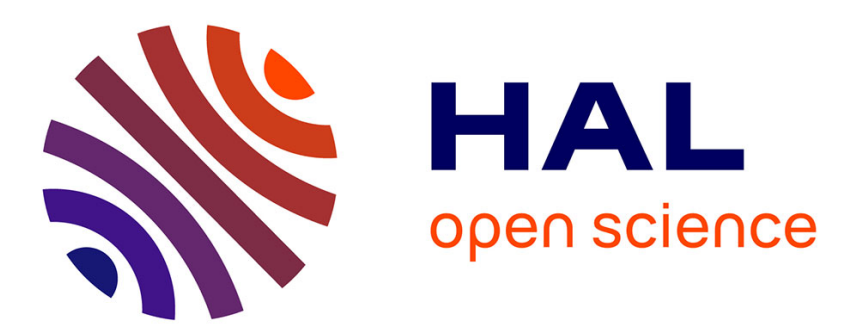

\title{
Towards the Clinical Use of Phytoplankton Carotenoid Pigments to Cure Cancer
}

\author{
Camille Juin, Valérie Thiéry, Jean-Paul Cadoret, Laurent Picot
}

\section{To cite this version:}

Camille Juin, Valérie Thiéry, Jean-Paul Cadoret, Laurent Picot. Towards the Clinical Use of Phytoplankton Carotenoid Pigments to Cure Cancer. oceanography, open access, 2013, 1 (3), 10.4172/23322632.1000e105 . hal-01247718

\section{HAL Id: hal-01247718 \\ https://hal.science/hal-01247718}

Submitted on 3 Sep 2018

HAL is a multi-disciplinary open access archive for the deposit and dissemination of scientific research documents, whether they are published or not. The documents may come from teaching and research institutions in France or abroad, or from public or private research centers.
L'archive ouverte pluridisciplinaire HAL, est destinée au dépôt et à la diffusion de documents scientifiques de niveau recherche, publiés ou non, émanant des établissements d'enseignement et de recherche français ou étrangers, des laboratoires publics ou privés. 


\section{Editorial}

Towards the clinical use of phytoplankton carotenoid pigments to cure cancer.

Juin $\mathbf{C}^{1}$, Thiéry $\mathrm{V}^{1}$, Cadoret $\mathrm{JP}^{2}$ and $\operatorname{Picot} \mathrm{L}^{\mathbf{1}^{*}}$.

1 Université de La Rochelle, UMRi CNRS 7266 LIENSs, 17042 La Rochelle, France.

2 Ifremer, Laboratoire BRM/PBA, Rue de l'Ile d'Yeu, 44311 Nantes, France.

* Corresponding author : Dr Laurent PICOT, 1picot@ univ-lr.fr

Beyond their major ecolophysiological functions, phytoplankton pigments exert biological and pharmacological activities in human cells that allows to consider their clinical use to cure various pathologies. Although much of our knowledge relating to their cell pharmacology and bioactivity has come from in vitro studies in cell culture models, recent in vivo studies have validated the potential of phytoplankton carotenoid pigments to limit inflammation and metabolic disorders, retinal diseases, degenerative diseases, tumor progression, and hepatotoxicity. Aside from these promising results, additional studies are now required to precise their pharmacokinetics, pharmacological targets, and clinical efficacy in humans. The availability of highly purified pigments at rational costs will be a milestone to set up clinical trials and develop new therapies using microalgae pigments. This short paper focuses on the great potential of phytoplankton carotenoid pigments to prevent and cure cancers.

Marine and freshwater microalgae have evolved a wide range of pigments that belong to the chlorophylls, carotenoids and phycobiliproteins families. Extensive research has proved that microalgae pigments exert significant biological and pharmacological activities in human cells. Beyond their well-known antioxidant activity, used as a commercial argument to sell algae-based cosmetics and nutraceutics, it is now clearly established that microalgae pigments have a great potential as health nutrients to prevent cancer, as biotechnological probes for cancer diagnosis and as anticancer drugs to trigger cancer cells apoptosis, prevent tumor angiogenesis, reduce the risk of metastasis, sensitize cancer cells to chemotherapy, destroy cancer cells by tumor phototherapy and filter UV to limit cancer cells initiation. Numerous studies aiming to identify antiproliferative molecules from microalgae extracts led to the isolation of carotenoids and to the demonstration of their high antiproliferative, cytostatic, cytotoxic, and/or pro-apoptotic activity in cancer cell cultures. As an example, our research team performed the bioguided isolation of pigments from Duniella tertiolecta and found that violaxanthin was the most antiproliferative molecule contained in $D t$ dichloromethane extract. We also recently reported the strong antiproliferative activity of zeaxanthin and $\beta$ cryptoxanthin in human invasive melanoma cells, after their bioguided isolation from Cyanophora paradoxa ethanolic extracts. 
Besides the purification of antiproliferative pigments, additional studies established that multiple cellular and molecular processes are affected by microalgae carotenoids. It was first demonstrated that their antioxidant activity protects against ROS-induced DNA mutations, and tissue and animals studies confirmed that most carotenoids effectively reduce the inflammatory processes initiated by carcinogenic agents, and thus prevent the risk of cancer initiation. As an example, adding peridinin in the dietary water of mice limits the development of carcinogens-induced skin tumors. Some authors also demonstrated that in addition to the cancer preventive effect associated to their antioxidant activity, some carotenoids such as fucoxanthin could trigger apoptosis in cancer cells by ROS generation. Pharmacological studies performed with fucoxanthin and various epoxycarotenoids confirmed that they affect a multitude of molecular and cellular targets dysregulated in cancer cells (cyclin-dependent kinases, DNA polymerases, connexins, pro and antiapoptotic proteins, MAP kinases, NF-kB, ...), and numerous studies are currently undertaken to precise the pharmacology of carotenoids, according to their high interest for human oncology. Beyond their cytotoxic activity, some carotenoids also inhibit the tumor neovascularization and the metastatic potential of cancer cells, reverse multi-drug resistance in cancer cells treated with chemotherapeutic agents, and alleviate the deleterious side effects of cytotoxic drugs. Fucoxanthin was particularly well studied and its clinical efficacy to cure cancers from various tissular origin is validated in animal models, and should soon be validated in humans. As a conclusion, it is obvious that microalgae carotenoids have a key role to play in clinical oncology and cancer nutritional prevention, according to their remarkable pharmacological activities. In addition to synthesizing most of the oxygen that we breathe, microalgae could thus have a great potential to help us fighting the second cause of death in developed countries.

\section{$\underline{\text { Selected papers from our research team: }}$}

Baudelet P.H., Gagez A.L., Bérard J.N., Juin C., Bridiau N., Kaas R., Thiéry V., Cadoret J.P. \& Picot L. Antiproliferative activity of Cyanophora paradoxa pigments in melanoma, breast and lung cancer cells. Marine Drugs 11(11), 4390-4406, 2013.

Serive B., Kaas R., Bérard J.B., Pasquet V., Picot L. \& Cadoret J.P. Selection and optimisation of a method for efficient metabolites extraction from microalgae. Bioresource technology 124, 311-320, 2012.

Mimouni V., Ulmann L., Pasquet V., Mathieu M., Picot L., Cadoret J.P., Morant-Manceau A. $\&$ Schoefs B. The potential of microalgae for the production of bioactive molecules of pharmaceutical interest (review). Current Pharmaceutical Biotechnology 13(15), 2733-2750, 2012.

Gagez A.L, Thiery V., Pasquet V., Cadoret J.P. \& Picot L. Epoxycarotenoids and cancer (review). Current Bioactive compounds 8(2), 109-141, 2012.

Pasquet V., Morrisset P., Ihammouine S., Chepied A., Aumailley L., Berard J.B., Serive B., Kaas R., Lanneluc I., Thiery V., Lafferiere M., Piot J.M., Patrice T., Cadoret J.P. \& Picot L. Antiproliferative activity of violaxanthin isolated from bioguided fractionation of Dunaliella tertiolecta extracts. Marine Drugs 9(5), 819-831, 2011. 
Pasquet V., Chérouvrier J.R., Farhat F., Thiéry V., Piot J.M., Bérard J.B.,Kaas R., Serive B., Patrice T., Cadoret J.P. \& Picot L. Study on the microalgal pigments extraction process:

Performance of microwave assisted extraction. Process Biochemistry 46(1), 59-67, 2011. 